\title{
Upaya Meningkatkan Hasil Belajar Siswa Pada Pembelajaran Sosiologi Melalui Model Discovery Learning Berbantuan Media Teka Teki Silang Puzzle Discovery Education Pada Siswa XI IIS SMA
}

\author{
Nia Novita Sari ${ }^{1}$, Junaidi Junaidi ${ }^{2}$ \\ ${ }^{1,2}$ Universitas Negeri Padang \\ Email: nianovitasarii75@gmail.com, junaidiunp@fis.unp.ac.id
}

\begin{abstract}
Abstrak
Penelitian ini dilatarbelakangi rendahnya hasil belajar siswa dalam pembelajaran sosiologi. Rendahya hasil belajar siswa disebabkan oleh tidak tepatnya strategi pembelajaran yang digunakan oleh guru, akibatnya siswa tidak fokus dalam belajar Untuk/mengatasi masalah rendah hasil belajar siswa guru menerapkan model discover learning berbasis media teka-teki silang puzzle discovery education. Penelitian ini bertujuan untuk meningkatkan hasil belajar siswa melalui model discover learning berbasis media teka teki silang puzzle discovery education dalam pembelajaran sosiologi. Penelitian ini merupakan penelitian tindakan kelas yang dilakukan dengan 2 siklus. Penelitian ini dilakukan di kelas XI IIS 4 SMAN 1 Nan Sabaris Padang Pariaman dilakukan secara daring melalui aplikasi whatsapp. Instrumen penelitian yang digunakan yaitu lembar observasi, dan catatan lapangan. Untuk melihat peningkatan setiap siklus diolah dengan menggunakan rumus Percentages Correction $\mathrm{S}=\mathrm{R} / \mathrm{Nx} 100$ pada siklus I naik sebanyak $17 \%$ sedangkan pada siklus II naik sebanyak 23\%. Untuk melihat keberhasilan belajar siswa hasil belajar diolah menggunakan rumus $(\mathrm{P}=\mathrm{F} / \mathrm{N}) \mathrm{X} 100 \%$. Adanya peningkatan hasil belajar siswa, dari pra tindakan $37 \%$, siklus I $54 \%$, siklus II $77 \%$.
\end{abstract}

Kata kunci: Discovery Learning, Hasil Belajar, Media Teka-Teki Silang, Pembelajaran Sosiologi

Abstract
This research was motivated by the low student learning outcomes in sociology learning. Low student learnin outcomes are caused by the inappropriate learning strategies used by the teacher, as a result students do not focus on learning. Solve the problem of low student earning outcomes the teacher applies a discovery learning model based on the crossword puzzle discovery education media. This study aims to improve student learning outcomes through the discovery learning model based on the crossword puzzle discovery education media in sociology learning. This research is a classroom action research conducted in 2 cycles. This research was conducted in class XI IIS 4 SMAN 1 Nan Sabaris Padang Pariaman and was conducted online through the Whatsapp application. The research instrument used was the observation sheet and field notes. To see the increase in each cycle, it is processed using the formula Percentages Correction $S=R / N x 100$ in the first cycle increased by $17 \%$ while in the second cycle it increased by 23\%. To see the learning success of students learning outcomes are processed using the formula $(P=F$ / N) X 100\%. There is an increase in student learning outcomes, from 37\% pre-action, 54\% first cycle, 77\% second cycle.

Keywords: Discovery Learning, Learning Outcomes, Media Crossword Puzzles, Sociology Learning

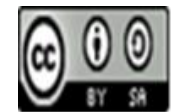

Received: February 20, $2021 \quad$ Revised: June 6, $2021 \quad$ Accepted: June 9, 2021 


\section{Pendahuluan}

Pendidikan merupakan usaha sistematis yang bertujuan agar setiap manusia mencapai satu tahapan tertentu dalam kehidupannya, yaitu tercapainya kebahagian lahir dan batin (Yusuf, 2014). Pendidikan juga merupakan suatu kekuatan yang dinamis dalam mempengaruhi kemampuan, kepribadian dan kehidupan individu dalam pertemuan dan pergaulannya dengan sesama, serta hubungannya dengan Tuhan (Rahayu \& Dwi, 2016). Pendidikan perlu dilaksanakan secara sadar dan terencana dalam mewujudkan proses pembelajaran dan suasana belajar agar peserta didik secara aktif, mengembangkan potensi diri untuk memiliki kekuatan spiritual, keagamaan, pengendalian diri, kecerdasan, kepribadian, berakhlak mulia, serta memiliki keterampilan yang diperlukan peserta didik, dengan tujuan peserta didik dapat hidup bermasyarakat, berbangsa dan Negara (Sulfemi \& Minati 2018). Oleh karena itu, pendidikan harus menerima, memberi perhatian, perawatan dan prioritas dari pemerintah (Hasibuan \& Sylvia, 2020).

Menurut UU No. 20 Tahun 2003 tentang Sisdiknas Pasal 1 ayat 20, "Pembelajaran adalah proses interaksi peserta didik dengan pendidik dan sumber belajar pada suatu lingkungan belajar" (Sanjaya, 2008). Pembelajaran adalah suatu proses yang mengandung rangkaian perbuatan guru dan siswa atas dasar hubungan timbal balik yang berlangsung dalam situasi edukatif untuk mencapai tujuan tertentu. Dalam pembelajaran terdapat sejumlah tujuan yang hendak dicapai. Pembelajaran dalam hal ini merupakan suatu kumpulan yang terdiri dari komponen-komponen pembelajaran yang saling berinteraksi, berintegrasi satu sama lainnya (Akhiruddin,dkk 2019). Menurut Budimansyah pembelajaran adalah sebagai perubahan dalam kemampuan, sikap, atau perilaku siswa yang relatif permanen sebagai akibat pengalaman atau pelatihan (Hayati, 2017). Menurut Trianto, pembelajaran adalah aspek kegiatan yang kompleks dan tidak dapat dijelaskan sepenuhnya. Secara sederhana, pembelajaran dapat diartikan sebagai produk interaksi berkelanjutan antara pengembangan dan pengalaman hidup (Pane, 2017). Pengalaman belajar dapat dilihat melalui prestasi belajar diwujudkan dalam prestasi akademik yang diukur melalui hasil belajar.

Hasil belajar adalah suatu pencapaian bentuk perubahan perilaku, pola-pola perbuatan, nilai-nilai, pengertian-pengertian, sikap-sikap, apresiasi, dan keterampilan yang cenderung menetap dari ranah kognitif, afektif, dan psikomotoris dari proses belajar yang dilakukan dalam waktu tertentu (Rahma \& Effendy, 2017). Menurut Dimyati \& Mujiono hasil belajar merupakan kemampuan-kemampuan yang dimiliki siswa setelah ia menerima pengalaman belajarnya. Untuk itu jika seorang pendidik bertanggung jawab atas penyempurnaan pembelajarannya, ia perlu melakukan mengevaluasi terhadap pembelajaran yang telah dilaksanakan untuk mengetahui perubahan apa yang harus dilakukan. Dapat disimpulkan bahwa hasil belajar adalah perubahan tingkah laku siswa berdasarkan pengalaman belajar yang diwujudkan dengan nilai tertentu serta berdampak pada perubahan kognitif, afektif, maupun psikomotorik.

Pembelajaran sosiologi adalah proses membelajarkan sosiologi kepada siswa baik keilmuan sosiologi maupun penerapannya dalam masyarakat, Adapun konsep yang dipelajari adalah struktur sosial dan proses-proses sosial termasuk perubahan-perubahan sosial. Struktur sosial adalah keseluruhan jalinan antara unsur-unsur sosial yang pokok yaitu kaidah-kaidah sosial (norma-norma sosial), lembaga-lembaga sosial, kelompok-kelompok serta lapisan-lapisan sosial. Proses sosial adalah pengaruh timbal balik antara berbagai segi kehidupan bersama (Soemardjan \& Soemardi, 1974). Menurut Ali Nurdin cakupan kajian sosiologi sangatlah luas mulai dari hubungan yang dinamis antar individu dan jaringannya sampai kajian tentang prosesproses sosial yang ada di seluruh dunia. (Nurdin, 1999) Hasil akhir dari pembelajaran diharapkan siswa memiliki kemampuan menjelaskan, menerapkan materi yang diperolehnya dan mampu mengembangan ilmu pengetahuannya sehingga tampak perubahan setelah 
Nia Novita Sari, Junaidi Junaidi Upaya Meningkatkan Hasil Belajar Siswa Pada Pembelajaran Sosiologi Melalui Model DiscoveryLearning berbasis Media TTS Puzzle Discovery EducationPada Siswa Xi Iis 4 Sman 1 Nan Sabaris Padang Pariaman

mengikuti pembelajaran (Sylvia, Anwar, \& Khairani, 2019). Namun berdasarkan pengamatan yang peneliti lakukan pada pembelajaran sosiologi di kelas IIS 4 SMAN 1 Nan Sabaris, ditemukan fakta bahwa siswa belum memiliki persiapan untuk mengikuti pembelajaran, siswa sibuk dengan kegiatan sendiri-sendiri, tidak fokus dalam belajar, sehingga hasil ujian siswa tidak sesuai dengan harapan. Pada tabel berikut dideskripsikan data data ujian tengah semester siswa kelas XI IIS 4 yang 63,3\% berada di bawah skor Kriteria Ketuntasan Minimal (KKM) yang ditetapkan.

\section{Tabel 1. Hasil Ujian Tengah Semester Pada Mata Pelajaran Sosiologi Kelas XI IIS 4 di SMAN 1 Nan Sabaris 2019/2020}

\begin{tabular}{cccccc|} 
Jumlah Siswa & KKM & Tuntas & \% Tuntas & Tidak Tuntas & \% Tidak Tuntas \\
\hline 30 & 76 & 11 & 36,67 & 19 & 63,3 \\
\hline \multicolumn{7}{c}{ Skor Tertinggi } & 90 & \\
\hline
\end{tabular}

Sumber: Data Guru Bidang Studi Sosiologi Kelas XI IIS 4 SMAN 1 Nan Sabaris

Berdasarkan tabel di atas, terlihat bahwa hanya 11 orang siswa yang dapat menguasai $76 \%$ materi dalam soal ujian tengah semester, sedangkan 19 orang memiliki penguasaan materi di bawah $76 \%$ dari materi yang dujikan. Untuk mengatasi permasalahan di atas perlu adanya pembaruan dalam pembelajaran. Guru harus dapat memberi pembelajaran yang mena rik siswa untuk aktif dan terlibat secara mental, sehingga hasil belajar akan lebih baik. Salah satu solusi yang dapat mengatasi permasalahan tersebut adalah dengan melakukan pembaharuan dalam proses pembelajaran yang melibatkan siswa secara aktif dalam langkahlangkah penemuan konsep dari fakta yang ditemukan sehingga terjadi pengalaman belajar bagi siswa. Salah satu model yang memiliki langkah-langkah pembelajaran sesuai dengan kondisi di atas adalah model discovery learning berbantuan media teka-teki silang puzzle discovery education.

Model discovery learning adalah suatu model pembelajaran yang diatur sedemikian rupa sehingga, siswa memperoleh pengetahuan yang belum diketahui namun tidak melalui penjelasan dari guru, akan tetapi akan ditemukan sendiri (Syaiful \& Dkk, 2017). Menurut Permendikbud Nomor 59 tahun 2014 model discovery learning dapat digunakan untuk materi yang memiliki dimensi pengetahuan faktual, konseptual dan prosedural (Yerimadesi, Putra, \& Ririanti, 2017). Model discoveri learning menekankan pentingnya pemahaman struktur atau ide-ide penting terhadap suatu disiplin ilmu melalui keterlibatan siswa secara aktif dalam pembelajaran. Siswa didorong untuk belajar sebagaian besar melalui keterlibatan aktif mereka sendiri dengan konsepkonsep, prinsip-prinsip dan guru mendorong siswa untuk memiliki pengalaman yang memungkinkan mereka menemukan prinsip untuk mereka sendiri. (Khaidir \& Rahmawati, 2015). Melalui model discovery learning, pembelajaran menekankan pada pengalaman langsung dan pentingnya pemahaman struktur atau ide-ide penting terhadap suatu disiplin ilmu, melalui keterlibatan siswa secara aktif dalam pembelajaran (Supriatna, 2018). Untuk mengatasi permasasalahan dalam pemmbelajaran sosiologi di kelas XI IIS 4 SMAN 1 Nan Sabaris peneliti menerapkan model discovery learning dipadukan dengan media pembelajaran teka-teki silang yang dibuat menggunakan aplikasi puzzle discovery education agar siswa dapat mengkonstruksi konsep dari fenomena sosial yang ada di sekitarnya, sehingga dapat menarik perhatian siswa dan siswa dapat belajar sambil bermain. Teka-teki silang adalah suatu permainan dimana siswa diminta untuk mengisi ruang- ruang kosong berbentuk kotak putih dengan huruf yang membentuk suatu kata yang merupakan jawaban atas suatu pertanyaan (Astuti \& Martini, 2013). Permainan teka-teki silang ini dapat membuat siswa lebih tertantang dalam 
mengerjakan soal yang telah diberikan oleh guru, selain itu siswa akan lebih memahami tentang materi yang telah diberikan, karena hal ini dapat mengatasi kejenuhan siswa yang selama ini hanya menjawab soal-soal (Wasgito, 2014). Dengan menggunakan teka-teki silang dalam pembelajaran akan mempermudah siswa untuk mengingat dan memahami konsep-konsep yang terkandung dalam pembelajaran (Nur, 2013).

\section{Metode Penelitian}

Penelitian ini merupakan jenis penelitian tindakan kelas yang bertujuan untuk meningkatkan hasil belajar siswa dalam pembelajaran sosiologi. Tindakan yang dilakukan untuk mengatasi permasalahan hasil belajar siswa adalah dengan memberikan media teka-teki silang puzzle discovery education melalui pembelajaran model discovery learning. Penelitian tindakan kelas ini dilakukan dalam dua siklus. Masing-masing siklus terdiri dari dua kali pertemuan yaitu empat jenis kegiatan dalam setiap pertemuannya yaitu perencanaan, tindakan, pengamatan, serta refleksi. Penelitian ini dilakukan di kelas XI IIS 4 SMAN 1 Nan Sabaris Padang Pariaman. Instrumen penelitian yang digunakan yaitu lembar observasi, catatan lapangan, dan soal untuk mengukur hasil belajar siswa di akhir siklus. Untuk menghitung peningkatan hasil belajar yang terjadi pada setiap pertemuannya digunakan rumus persentase. (Arikunto, 2008).

\section{Hasil Penelitian dan Pembahasan}

Penelitian tindakan ini dimulai dari tahap pra tindakan. Pada tahap pra tindakan, peneliti mengumpulkan data hasil belajar peserta didik sebelum tindakan dilakukan. Berikut data hasil belajar siswa yang diperoleh sebagai dasar peneliti merumuskan bahwa terdapat permasalah dalam proses pembelajaran dan hasil belajar siswa.

Tabel 2. Persesentase Hasil Belajar Pra Tindakan Kelas XI IIS 4 SMAN 1 Nan Sabaris.

\begin{tabular}{|c|c|c|c|c|}
\hline No & Rentan Nilai & KKM & Klasifikasi Nilai & Jumlah Siswa \\
\hline 1 & $86-100$ & \multirow[t]{4}{*}{76} & A & 1 \\
\hline 2 & $81-85$ & & B & 0 \\
\hline 3 & $75-80$ & & $\mathrm{C}$ & 10 \\
\hline 4 & $<75$ & & $\mathrm{D}$ & 19 \\
\hline
\end{tabular}

Sumber: Data Guru Bidang Studi Sosiologi Kelas XI IIS 4 SMAN 1 Nan Sabaris 2019

Tabel di atas memperlihatkan bahwa ditemukan masalah dalam hasil belajar siswa. Hanya 1 orang siswa yang nilainya A dan tidak ada siswa yang memiliki nilai B, sedangkan 29 siswa memiliki nilai $C$ dan D. Selain itu juga diperoleh data melalui observasi bahwa siswa tidak memiliki persiapan dalam belajar, siswa sibuk dengan kegiatan sendiri-sendiri, sehingga hasil belajar yang mereka dapatkan memang jauh dari harapan. Sementara KKM yang ditetapkan mengharuskan masing-masing siswa mampu menguasai minimal $76 \%$ dari materi yang mereka pelajari.

Berdasarkan hasil kegiatan pra tindakan diperoleh data bahwa hanya 36,67\% siswa yang tuntas dan termasuk kategori rendah. Refleksi yang peneliti lakukan dengan guru yang bertindak sebagai kolaborator adalah berusaha meningkatkan hasil belajar sosiologi siswa kelas XI IIS 4 SMAN 1 Nan Sabaris dengan menerapkan pembelajaran melalui model discovery learning berbasis media teka-teki silang puzzle discovery education pada materi integrasi sosial. 
Nia Novita Sari, Junaidi Junaidi Upaya Meningkatkan Hasil Belajar Siswa Pada Pembelajaran Sosiologi Melalui Model DiscoveryLearning berbasis Media TTS Puzzle Discovery EducationPada Siswa Xi Iis 4 Sman 1 Nan Sabaris Padang Pariaman

\section{Hasil Tindakan Siklus I}

\section{Pertemuan 1}

\section{Perencanaan}

Pada tahap perencanaan ini, peneliti terlebih dahulu menyusun perencanaan agar tujuan penelitian bisa tercapai. Adapun kegiatan yang peneliti lakukan adalah :

1) Menyiapkan dan menyusun rencana pelaksanaan pembelajaran.

2) Mempersiapkan bahan ajar dan media yang dapat membantu memudahkan siswa saat belajar daring.

3) Mempersiapkan tugas individu siswa berupa soal yang berbentuk masalah dan dijawab oleh berupa konsep yang diisi dalam TTS setiap kali pertemuan.

4) Mempersiapkan lembar observasi. education

Berikut bentuk teka-teki silang yang telah peneliti rancang melalui aplikasi puzzle discovery

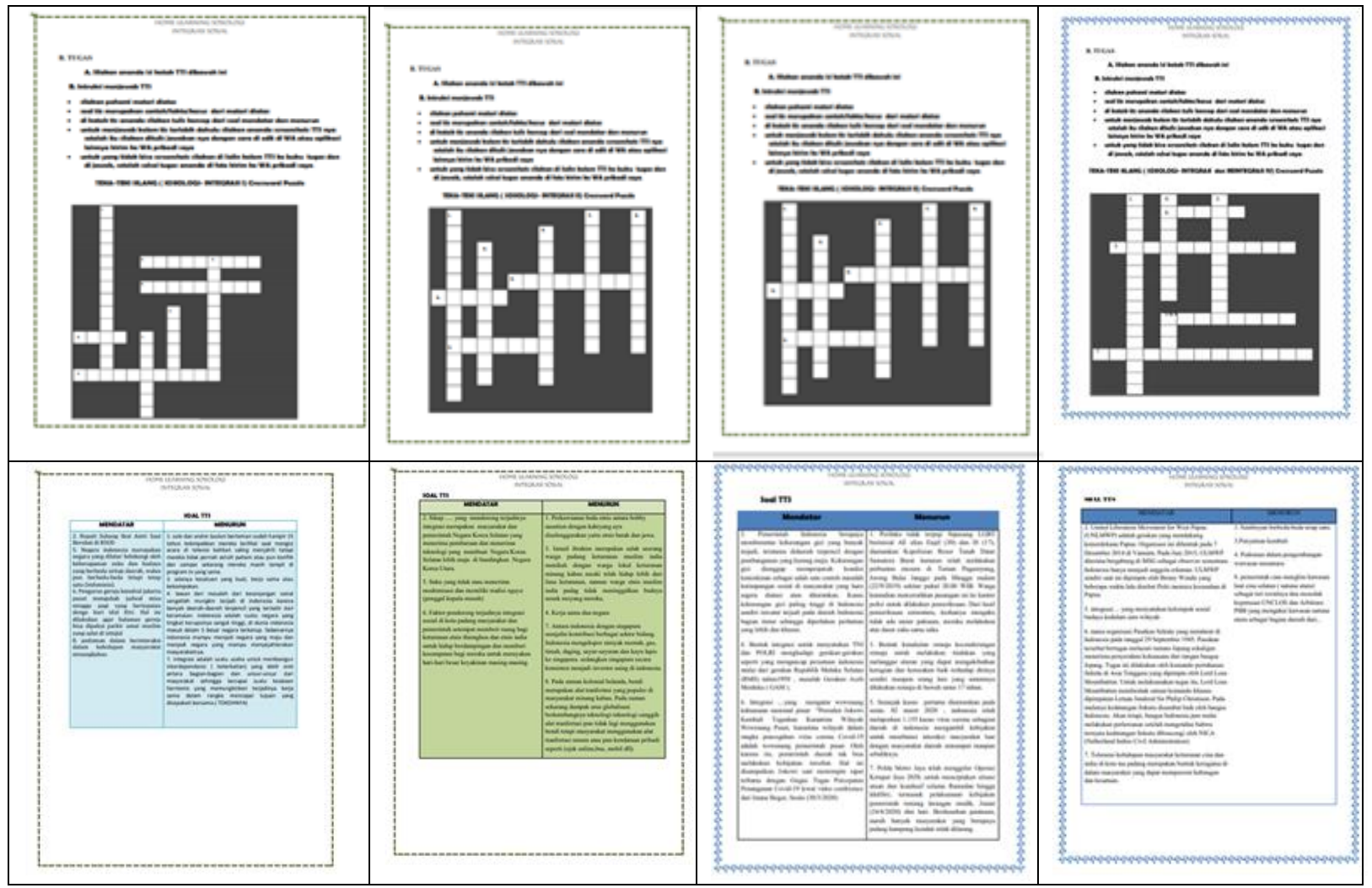

Gambar 1. Rancangan Teka-Teki Silang Menggunakan Aplikasi Puzzle Discovery Education yang digunakan untuk 4 kali pertemuan 


\section{Pelaksanaan}

\section{Penerapan Model Discovery Learning Berbasis Media Teka-Teki Silang Puzzle Discovery Education}

\section{Kegiatan Awal}

Pertemuan pertama siklus I dilakukan pada hari Selasa, 24 Maret 2020 mulai pada jam 11:00 - 12:30 WIB. Pembelajaran berlangsung selama 90 menit. Kegiatan awal yang dilakukan guru terlebih dahulu adalah membuka pembelajaran dengan mengucap salam, menyapa dan menanyakan kabar siswa. Selanjutnya guru memeriksa kehadiran siswa dan menyampaikan tujuan pembelajaran yang harus dicapai oleh siswa. Pada pertemuan pertama ini materi yang akan dipelajari adalah klasifikasi syarat-syarat terjadinya integrasi sosial.

\section{Kegiatan Inti}

Sebelum memulai pembelajaran, guru terlebih dahulu memberi bahan ajar dalam bentuk presentasi power point. Siswa diberi kesempatan untuk membaca dan memahami bahan ajar. Pada pembahasan materi, guru menanyakan kepada siswa mengenai materi yang tidak mereka pahami dari bahan ajar yang diberikan. Siswa memberikan respon memahami materi tersebut sebanyak 18 orang dan 2 orang tidak memahaminya. Adapun materi yang tidak dipahami oleh siswa adalah syarat-syarat terjadinya integrasi sosial yaitu adanya nilai dan norma sosial yang dilestarikan untuk pedoman interaksi. Kemudian guru memberikan kesempatan kepada siswa lainnya untuk menanggapi terlebih dahulu. Ada dua orang siswa yang mampu menjawab pertanyaan ini yaitu, salah satunya DS menjawab pertanyaan dari LH, yaitu:

"seperti yang telah dijelaskan di bahan ajar bahwa integrasi sosial adalah penyesuaian unsur-unsur yang berbeda dalam masyarakat sehingga menjadi satu kesatuan seperti unsur ras, etnis atau pun bahasa. Sedangkan syarat terjadinya integrasi sosial adalah adanya norma dan nilai sosial yang dilestarikan untuk pedoman interaksi menurut saya kenapa norma dan nilai untuk pedoman interaksi kareana nilai dan norma lah yang sebagai pengatur tatanan masyarakat."

Siswa lainnya tidak ada lagi yang menanggapi pernyataan tersebut. Selanjutnya guru melaksanakan diskusi dan tanya jawab dengan siswa sehubungan dengan materi syarat terjadiya integrasi sosial. Setelah dirasa mencapai kesepakatan, selanjutnya guru membagikan dan memberi tugas kepada siswa berbentuk teka-teki silang puzzle discovery education.

\section{Kegiatan Penutup}

Pada kegiatan ini, siswa dibimbing oleh guru untuk membuat kesimpulan materi syarat integrasi sosial setelah mereka mengerjakan teka-teki silang yang menjadi tugas masing-masing siswa. Selanjutnya guru memberi pujian dan reward terhadap siswa yang bertanya dan menanggapi pertanyaan dari temannya pada pertemuan pertama. Reward yang diberikan berupa nilai tambahan untuk pertemuan pertama. Guru menyampaikan kekurangan pembelajaran pada materi syarat terjadinya integrasi sosial (pertemuan 1) dan meminta pertemuan selanjutnya banyak yang terlibat dalam pembelajaran.

\section{Pertemuan II}

\section{Pelaksanaan}

Pertemuan kedua siklus I dilakukan pada hari Kamis, 31 Maret 2020 mulai pada jam 11:00 - 12:30 WIB. Pembelajaran berlangsung selama 90 menit. 


\section{Kegiatan Awal}

Kegiatan awal dilakukan guru terlebih dahulu mengucap salam dan menyapa kabar siswa. Selanjutnya guru memeriksa kehadiran siswa. Sebelum memulai pelajaran guru menyampaikan tujuan pembelajaran yang harus dicapai siswa yaitu siswa mampu mengklasifikasikan faktor pendorong terjadinya integrasi sosial.

\section{Kegiatan Inti}

Guru terlebih dahulu melakukan apersepsi agar siswa dapat mengingat kembali pembelajaran minggu lalu. Guru meminta kepada siswa yang bisa memberi contoh dari integrasi sosial. Ditanggapi yang pertama oleh DMH contoh dari integrasi di sekolah yaitu tidak memandang derajat si kaya dan si miskin, di sekolah semuanya sama. Kemudian siswa dengan inisial NKP menanggapi contoh integrasi sosial "Bhinneka Tunggal Ika" berbeda-beda tetap satu. Kemudian guru melanjutkan dengan memberi bahan ajar berupa presentasi power point yang dibagikan ke grup whattsap kelas XI IIS 4. Bahan ajar tersebut akan di download siswa melalui aplikasi whatsapp yang ada di smartphone masing-masing siswa. Setelah di download siswa diberi waktu 15 menit untuk membaca dan memahami materi pertemuan kedua yaitu faktor pendorong terjadinya integrasi sosial. Setalah itu guru meminta siswa untuk menanggapi materi yang belum dipahami, siswa menjawab bahwa mereka sudah memahaminya. Pada pertemuan ini jumlah 21 siswa yang hadir dan 2 orang siswa menanggapi pertanyaan dari guru.

Selanjutnya pertanyaan muncul dari siswa dengan inisial DMH yaitu "buk saya belum paham materi, mengenai tidak adanya toleransi bisa menjadi faktor penghambat integrasi". Kemudian dilanjutkan oleh NA yang menanyakan "saya belum paham dengan identifikasi merupakan proses terjadinya integrasi". Kemuduian guru meminta siswa lain untuk menjawab pertanyaan dari temannya dan menanggapinya. Pertanyaan dari $\mathrm{DMH}$ ditanggapi oleh DS dengan jawaban "tidak adanya toleransi akan menghambat integrasi karena tidak adanya toleransi berarti tidak ada rasa saling menghargai yang akan menimbulkan permasalahan dalam kehidupan bermasyarakat". Pertanyaan dari NA ditanggapi oleh RS yaitu "identifikasi adalah masyarakat yang membuka diri terhadap pihak lain".

Guru meminta siswa mencari contoh lain dari materi yang dipelajari hari tersebut dari sumber literasi lainnya dan di lingkungan sekitar mereka. Hasil temuan siswa tersebut disalin ke buku tugas dan disampaikan melalui voice note yang dikirim ke grup kelas. Selanjutnya guru memberi tugas kepada siswa berbentuk teka-teki silang puzzle discovery education yang sudah di konversi ke dalam bentuk file pdf. Tugas tersebut kemudian dikerjakan oleh siswa dan dikumpulkan kembali kepada guru melalui aplikasi whatsapp.

\section{Kegiatan Akhir}

Siswa dibimbing oleh guru untuk membuat kesimpulan materi hari ini. Setelah ditanggapi siswa, guru memberi pujian dan reward terhadap siswa yang berani untuk menanggapi pertanyaan yang diberikan oleh guru ataupun teman sekelas, siswa tersebut diberi reward berupa nilai tambahan. Guru menyampaikan kekurangan pembelajaran pada pertemuan tersebut dan meminta pada pertemuan selanjutnya lebih meningkat lagi siswa dalam meberikan respon pada saat pembelajaran berlangsung. Selanjutnya guru memberi informasi materi pertemuan berikutnya bentuk-bentuk integrasi sosial. Terakhir guru mengucapkan syukur dan salam. Berdasarkan pengamatan pada siklus I terjadi peningkatan hasil belajar siswa dibandingkan dengan tahap pratindakan, peningkatanya dapat dilihat pada tabel berikut: 
Nia Novita Sari, Junaidi Junaidi Upaya Meningkatkan Hasil Belajar Siswa Pada Pembelajaran Sosiologi Melalui Model DiscoveryLearning berbasis Media TTS Puzzle Discovery EducationPada Siswa Xi Iis 4 Sman 1 Nan Sabaris Padang Pariaman

Tabel 3. Persentase Hasil belajar pratindakan dan siklus I di kelas XI IIS4 SMAN 1 Nan Sabaris.

\begin{tabular}{|c|c|c|c|c|c|c|c|}
\hline No & $\begin{array}{l}\text { Rentan } \\
\text { Nilai }\end{array}$ & KKM & $\begin{array}{l}\text { Klasifikasi } \\
\text { Nilai }\end{array}$ & $\begin{array}{l}\text { Jumlah Siswa } \\
\text { Pratindakan }\end{array}$ & $\begin{array}{c}\text { \%Pra } \\
\text { Tindakan }\end{array}$ & $\begin{array}{c}\text { Jumlah } \\
\text { Siswa } \\
\text { Siklus I }\end{array}$ & $\begin{array}{c}\% \\
\text { Siklus I }\end{array}$ \\
\hline 1 & $86-100$ & \multirow{4}{*}{76} & A & 1 & \multirow{4}{*}{$37 \%$} & 11 & \multirow{4}{*}{$54 \%$} \\
\hline 2 & $81-85$ & & B & 0 & & 5 & \\
\hline 3 & $75-80$ & & C & 10 & & 1 & \\
\hline 4 & $>74$ & & $\mathrm{D}$ & 19 & & 17 & \\
\hline
\end{tabular}

Sumber: Pengamatan Pra Tindakan dan Siklus I Tahun 2020

Berdasarkan tabel di atas, perbandingan pra tindakan dan pada siklus I mengalami peningkatan $17 \%$. Pra tindakan $37 \%$ sedangkan pada siklus satu jumlah rata-rata nilai pada pertemuan I dan II yaitu 54\%, termasuk dalam kategori cukup.Berdasarkan proses pengamatan pada siklus I terlihat peningkatan hasil belajar siswa sebanyak 17\%. Untuk itu masih perlu dilakukan perbaikan sehingga mencapai target sesuai KKM. Peneliti melanjutkan tindakan pada siklus II dengan cara memperbaiki Tindakan yang perlu dilakukan oleh guru yaitu: 1) Guru akan membuat materi / bahan ajar lebih menarik. 2) Guru akan menyederhanakan bahasa dalam soal teka-teki silang puzzle discovery education supaya siswa bisa mudah menjawabnya. 3) Guru memberi motivasi agar siswa berusaha mempelajrai dan mengingat kembali materi minggu lalu sebelum belajar. 4) Guru akan melibatkan siswa untuk mencari contoh realita yang ada di sekitar ruang lingkup lingkungan siswa ataupun melalui sumber belajar yang ada di internet. 5) Guru membimbing siswa untuk menampilkan hasil pencarian siswa/hasil diskusi siswa. 6) Guru memberi nilai tambahan kepada siswa yang mau bertanya, dan menjawab pertanyaan/ menanggapi dengan cara mengumumkan pada akhir proses pembelajaran. 7) Guru meminta siswa untuk membaca sumber belajar yang lain untuk persiapan pemebelajaran berikutnya.

\section{Hasil Tindakan Siklus II}

Siklus kedua dilakukan dalam dua kali pertemuan yaitu pada hari Selasa, 7 April 2020 dan 14 April 2020. Pembelajaran berlangsung selama 90 menit. Pembelajaran dilakukan secara daring (online) pada kelas XI IIS 4 yang berjumlah 30 siswa.

\section{Pertemuan 1}

\section{Perencanaan}

Berdasarkan refleksi pada siklus I diputuskan untuk melanjutkan ke siklus II agar terjadi peningkatan hasil belajar siswa dan dapat mencapai KKM. Pada siklus II peneliti melakukakn perencanaan untuk setiap kelangkapan dan tindakan yang akan dilakukan. Ada beberapa yang peneliti lakukan pada tahap ini yaitu:

1. Menyusun/ menyiapkan rencana pelaksanaan pembelajaran

RPP disiapkan untuk satu kali pertemuan dengan model discovery learning berbasis media tekateki silang puzzle discovery education pada materi pengertian integrasi sosial dan syarat terjadinya integrasi sosial.

2. Mempersiapkan bahan ajar yang menarik dan media yang dapat membantu memudahkan siswa saat belajar daring.

3. Mempersiapkan tugas individu siswa, dan hasilnya akan di kirim ke grup kelas

4. Mempersiapkan lembar observasi

Lembar observasi berisi aspek yang diamati pelaksanaan guru dalam implementasi model discovery learning berbasis media teka-teki silang puzzle discovery education. Hasil dari 
Nia Novita Sari, Junaidi Junaidi

Upaya Meningkatkan Hasil Belajar Siswa Pada Pembelajaran Sosiologi Melalui Model DiscoveryLearning berbasis Media TTS Puzzle Discovery EducationPada Siswa Xi Iis 4 Sman 1 Nan Sabaris Padang Pariaman

pengamatan dari lembar observasi akan manggambarkan kegiatan pembalajaran yang dilakukan.

5. Merencanakan pemberian nilai tambahan kepada siswa yang mau bertanya, dan menjawab pertanyaan/ menanggapi dengan cara mengumumkan pada akhir proses pembelajaran.

\section{Pelaksanaan Tindakan}

\section{Kegiatan Awal}

Kegiatan awal dilakukan guru terlebih dahulu mengucap salam dan menyapa kabar siswa. Selanjutnya guru memeriksa kehadiran siswa. Sebelum memulai pelajaran guru menyampaikan tujuan pembelajaran yang harus dicapai siswa yaitu siswa diharapkan mampu menganalisis bentuk-bentuk integrasi sosial

\section{Kegiatan Inti}

Guru memberikan motivasi kepada siswa agar selalu berperan aktif dalam kegiatan diskusi, guru juga memberi apersepsi. Apersepsi tersebut disampaikan guru untuk dihubungkan dengan materi hari ini. Selanjutnya sebelum memulai pembelajaran, guru telebih dahulu memberi bahan ajar berupa bahan ajar dari presentasi power poin yang dibagikan ke grup whatsapp kelas XI IIS 4. Bahan ajar tersebut akan di download siswa melalui aplikasi whatsapp yang ada di smartphone siswa, setelah di dowload siswa diberi waktu 15 menit untuk membaca dan memahami materi yang diberikan oleh guru. Materi dipertemuan ke tiga yaitu bentukbentuk integrasi sosial.

Setelah bahan ajar dibaca oleh siswa, guru melanjutkan pada sesis tanya jawab. Guru meminta siswa untuk mengajukan pertanyaan dari pembahasan materi pada pertemuan bentukbentuk integrasi sosial. Pada pertemuan ke tiga ini muncul 9 pertanyaan. Pertanyaan pertama diajukan oleh DS "apakah perbedaan integrasi sosial dan integrasi nasional?". Pertanyaan ke dua diajukan oleh AIM "kenapa lagu kebangsaan dapat dikatakan bentuk integritas nasional?". Pertanyaan ke diajukan oleh tiga DA "apakah hukum adat termasuk integrasi koersif?" Kemudian pertanyaan ke empat diajukan oleh RS "apakah contoh dari integrasi elit-massa?". Pertanyaan ke lima diajukan oleh PAU "saya belum paham integrasi wilayah, bisa dijelaskan kembali Bu?." Pertanyaan ke enam oleh SJ Bsekarang ini ada aturan masyarakat diwajibkan menggunakan masker untuk menghindari covid-19, apakah itu bisa dikatakan integrasi Bu?". Pertanyaan ke tujuh diajukan oleh SYA "Bagaimanakah bentuk integrasi tingkah laku?". Pertanyaan ke delapan dari MIS "kenapa bhinneka tunggal ika termasuk integrasi normatif?" pertanyaan ke sembilan ND yang membelatar belakangi munculnya integrasi normatif ?".

Setelah siswa bertanya mengenai materi yang belum mereka pahami, guru meminta siswa lainnya untuk terlebih dahulu menanggapi pertanyaan yang telah disampaikan oleh temantemannya. Dari 9 pertanyaan tersebut ada 8 orang siswa lainnya yang mampu memberikan pernjelasan. Guru memberikan penjelasan atas pertanyaan yang tidak dapat dijawab oleh siswa. Selanjutkan guru juga memberikan penguatan materi.

Setelah siswa mampu memahami materi tersebut makan guru membagi media teka-teki silang puzzle discovery education yang telah di buat menjadi file pdf yang memudahkan siswa untuk membukanya dan dikirimkan melalui grup kelas. Guru membimbing siswa untuk mengetahui tata cara menjawab teka-teki silang puzzle discovery education tersebut. Guru meminta hasil kerja siswa dikirim ke whatsapp pribadi guru. Guru mengevaluasi hasil tugas tersebut dan membandingkannya dengan siklus 1 , sehingga dapat diketahui penguasaan materi siswa setelah selesai pembelajaran.

\section{Kegitan Penutup}

Siswa dibimbing oleh guru untuk menyimpulkan materi bentuk-bentuk integrasi sosial. Guru memberi pujian dan reward terhadap siswa yang bertanya dan menanggapi pertanyaan dari 
Nia Novita Sari, Junaidi Junaidi

Upaya Meningkatkan Hasil Belajar Siswa Pada Pembelajaran Sosiologi Melalui Model DiscoveryLearning berbasis Media TTS Puzzle Discovery EducationPada Siswa Xi Iis 4 Sman 1 Nan Sabaris Padang Pariaman

temannya di pertemuan ke 3. Reward yang diberikan berupa nilai tambahan untuk hari ini dan guru menyebut nama beserta nilai yang didapat oleh siswa yang sudah ikut bertanya, menjawab pertanyaan dan memberikan tanggapan. Guru menyampaikan kekurangan pembelajaran hari ini dan memberi informasi materi pertemuan berikutnya.

\section{Pertemuan ke 2 Siklus II}

\section{Pelaksanaan Tindakan}

Pertemuan II siklus II dilakukan pada Selasa 14 April 2020 mulai pada jam 11:00 - 12:30 WIB. Pembelajaran berlangsung selama 90 menit menggunakan aplikasi whatshapp.

\section{Kegiatan Awal}

Kegiatan awal dilakukan guru terlebih dahulu mengucap salam dan menyapa kabar siswa. Selanjutnya guru memeriksa kehadiran siswa. Sebelum memulai pelajaran guru menyampaikan tujuan pembelajaran yang harus dicapai siswa. Siswa diharapkan mampu menganalisis integrasi dan reintegrasi.

\section{Kegiatan Inti}

Guru memberikan motivasi tetap semangat belajar walaupun secara daring memiliki keterbatasan. Guru menyampaikan apersepsi kepada siswa dengan memberikan ilustrasi kasus konflik yang pernah terjadi di Surabaya. Apersepsi tersebut disampaikan guru untuk dihubungkan dengan materi hari ini. Sebelum memulai pembelajaran, guru terlebih dahulu memberi bahan ajar yang dibagikan ke grup whattsap kelas XI IIS 4. Guru menjelaskan secara garis besar menjelaskan materi pertemuan sebelumnya dan keterkaitannya dengan konsep reintegrasi sosial. Siswa diberi waktu 15 menit untuk membaca dan memahami materi yang diberikan oleh guru. Pada pertemuan ke empat ini materi yang dibelajarkan adalah reintegrasi sosial.

Setelah bahan ajar dibaca oleh siswa, kemudian guru meminta siswa untuk mengajukan pertanyaan Pada sesi tanya jawab ini muncul 11 pertanyaan dari siswa dan 15 orang siswa yang memberikan jawaban. Selanjutnya guru memberikan teka-teki silang puzzle discovery education untuk mengevaluasi peguasaan konsep siswa pada materi reintegrasi sosial. Hasil ini akan Pada Siswa dibimbing oleh guru untuk menyimpulkan materi hari ini.

Guru memberi pujian dan reward terhadap siswa yang bertanya dan menanggapi pertanyaan dari temannya di pertemuan ke II. Reward yang di berikan berupa nilai tambahan untuk hari ini dan guru menyebut nama beserta nilai yang didapat oleh siswa yang sudah ikut bertanya dan menjawab pertanyaan. Guru menyampaikan kekurangan pembelajaran hari ini dan guru juga menyampaikan perkembangan yang baik dalam pembelajaran. Berdasarkan proses yang telah dilakukan pada siklus II dapat dilihat adanya peningkatan hasil belajar siswa dibandingkan pra tindakan dan siklus I, peningkatan tersebut dapat dilihat pada tabel berikut:

Tabel 4. Persentase Hasil Belajar Pada Siklus II di kelas XI IIS4 SMAN 1 Nan Sabaris.

\begin{tabular}{|c|c|c|c|c|c|c|c|c|c|}
\hline No & $\begin{array}{c}\text { Rentang } \\
\text { Nilai }\end{array}$ & KKM & $\begin{array}{l}\text { Klasifikasi } \\
\text { Nilai }\end{array}$ & $\begin{array}{c}\text { Jumlah } \\
\text { Siswa } \\
\text { (Pra } \\
\text { TIndakan) }\end{array}$ & $\begin{array}{c}\% \\
\text { Pra } \\
\text { Tindak } \\
\text { an }\end{array}$ & $\begin{array}{c}\text { Jumlah } \\
\text { Siswa } \\
\text { SI }\end{array}$ & $\begin{array}{l}\% \\
\text { S I }\end{array}$ & $\begin{array}{c}\text { jumlah } \\
\text { Siswa } \\
\text { Siklus } \\
\text { II }\end{array}$ & $\begin{array}{c}\% \\
\text { S II }\end{array}$ \\
\hline 1 & $86-100$ & \multirow{4}{*}{76} & A & 1 & \multirow{4}{*}{$37 \%$} & 11 & \multirow{4}{*}{$54 \%$} & 22 & \multirow{4}{*}{$77 \%$} \\
\hline 2 & $81-85$ & & B & 0 & & 5 & & 2 & \\
\hline 3 & $75-80$ & & $C$ & 10 & & 1 & & 0 & \\
\hline 4 & $>74$ & & $\mathrm{D}$ & 19 & & 17 & & 6 & \\
\hline
\end{tabular}

Sumber: Hasil Belajar Pada Siklus II 
Pada siklus II peneliti mendapatkan hasil beajaar siswa termasuk dalam kategori baik. Dan terdapat peningkatan hasil belajar sebesar 23\% dari siklus I. Pada pertemuan III siklus II rata-rata nilai siswa memperoleh 74 dan pada pertemuan IV siklus II rata-rata nilai siswa memperoleh 80. Hasil ini diperoleh dari skor siswa mengerjakan teka-teki silang puzzle discovery education yang terdiri dari 8 soal untuk setiap pertemuan. Dengan demikian target dalam penelitian ini telah tercapai yaitu hasil belajar siswa kelas XI IIS4 SMA N 1 Nan Sabaris dalam kategori baik. Berdasarkan teori kognitif dikemukakan Jarome Bruner mengatakan belajar adalah suatu proses seseorang mengatur pesan atau informasi dan bukan ditentukan oleh umur. Proses belajar akan berjalan dengan baik jika materi pelajaran atau informasi baru beradaptasi dengan struktur kognitif yang dimiliki dan telah terbentuk didalam pikiran seseorang berdasarkan pemahaman dan pengalaman-pengalaman sebelumnya. Hasil belajar siswa meningkat karena adanya aktivitas belajar yang dilakukan oleh siswa secara aktif, siswa mudah memahami materi yang disampaikan menggunakan contoh yang fakta. Guru memberi bahan ajar kepada siswa, memberika terdapat teka-teki silang puzzle discovery education untuk mengukur kemampuan siswa memahami materi dan membuat pembelajaran menyenangkan. Pemahaman materi siswa bisa dilihat dari adanya hasil peningkatan hasil belajar yang diperoleh siswa 4 kali pertemuan.

\section{Kesimpulan}

Berdasarkan hasil yang di peroleh selama penelitian secara daring (online) pada aplikasi whatsapp dapat.disimpulkan model discovery learning/berbasis.media teka-teki silang puzzle discovery education dapat meningkatkan hasil belajar siswa dalam pembelajaran sosiologi di kelas XI IIS 4 SMA N 1 Nan Sabaris. Data dari peningkatan hasil belajar siswa kelas XI IIS 4 SMA N 1 Nan Sabaris. Secara keseluruahan hasil belajar siswa meningkat dari..pra..tindakan sebesar $37 \%$ menjadi $54 \%$, peningkatannya sebesar $17 \%$. Kemudia dari siklus I sebesar $54 \%$ ke siklus II sebanyak $77 \%$, peningkatan sebesar $23 \%$. Dengan menggunakan media teka-teki silang puzzle discovery education juga membuat siswa lebih memahami konsep karena tugas yang ditampilkan dalam media pembelajaran yaitu fakta yang terjadi pada masa sekarang atau pun kasus yang terlah terjadi, hal tersebut memudahkan siswa untuk menebak konsep materi pembelajaran. Penggunaan media teka-teki silang puzzle discovery education tidak membuat siswa merasa membosankan, sehingga siswa ingin menyelsaikan tugas yang diberikan oleh guru, akhinya dapat meningkatan hasil belajar siswa.

\section{Daftar Pustaka}

Akhiruddin, A., Sujarwo, S., Atmowardoyo, A., Haryanto, H., \& Nurhikmah, N. (2019). Belajar dan Pembelajaran. Makassar: CV. Cahaya Bintang Cemerlang.

Arikunto, S. (2008). Penelitian Tindakan Kelas. Jakarta: Bumi Aksara.

Astuti, H., \& Martini, K. S. (2013). Efektivitas Penggunaan Media TTS dan Kartu Soal di Semester Genap SMAN Colamadu Karanganyar. Jurnal Pendidikan Kimia, 2(1), 85-91.

Hasibuan, R. F., \& Sylvia, I. (2020). Upaya Peningkatan Hasil Belajar Siswa Melalui Penerapan Strategi Inquiry Pada Pembelajaran Sosiologi Kelas XI IPS di SMAN 1 Batang Gasan. Jurnal Sikola: Jurnal Kajian Pendidikan Dan Pembelajaran, 2(1), 44-52.

Hayati, S. (2017). Belajar dan Pembelajaran Berbasis Cooperative Learning. Magelang: Graha Candikia.

Nur, M. (2013). Meningkatan Hasil Belajar Siswa Melalui Penggunaan Teka-Teki Silang (TTS) Pada Pembelajaran Sejarah Kelas XI IPS 1 SMAN 3 Bantul Tahun Ajaran 2012/2013. Universitas Negeri Yogyakarta. 
Nia Novita Sari, Junaidi Junaidi Upaya Meningkatkan Hasil Belajar Siswa Pada Pembelajaran Sosiologi Melalui Model DiscoveryLearning berbasis Media TTS Puzzle Discovery EducationPada Siswa Xi Iis 4 Sman 1 Nan Sabaris Padang Pariaman

Nurdin, N. (1999). Sosiologi Organisasi: Pengertian, Sejarah Lahirnya, Ruang Lingkup, Manfaat dan Metode Penelitian. Jakarta: Modul Sosiologi.

Pane, A. (2017). Belajar dan Pembelajaran. Fitrah:Jurnal Kajian Ilmu-Ilmu Keislaman, 3(2), 333352.

Rahayu, F. K., \& Dwi, D. (2016). Pengaruh Penerapan Model Pembelajaran Discovery Learning Terhadap Hasil Belajar IPS Pada Siswa Kelas IV SD. Scholaria, 6(1), 84-92.

Rahma, Q., \& Effendy, U. (2017). Penerapan Media Teka-Teki Silang Untuk Meningkatkan Hasil Belajar Ips Kelas Ivb Sd Negeri 24 Palembang. Jurnal Inovasi Sekolah Dasar, 4(20), 2.

Rahmawati, \& Kadri, M. (2015). Pengaruh Model Pembelajaran DIscovery Learning Terhadap Hasil Belajar Siswa Materi Kalor. Universitas Negeri Medan.

Sanjaya, W. (2008). Kurikulum dan Pembelajaran: Teori dan Praktik Pengembangan Kurikulum Tingkat Satuan Pendidikan (KTSP). Jakarta: Kencana.

Soemardjan, S., \& Soemardi, S. (1974). Setangkai Bunga Sosiologi. Jakarta: Lembaga Penerbitan FEUI.

Sulfemi, W. B., \& Minati, H. (2018). Meningkatkan Hasil Belajar Peserta Didik Kelas 3 Sd Menggunakan Model Picture and Picture Dan Media Gambar Seri. Jurnal Pendidikan Sekolah Dasar, 4(2), 228. https://doi.org/10.30870/jpsd.v4i2.3857

Supriatna, D. (2018). Meningkatkan Hasil Belajar Pendidkan Agama dan Budi Pekerti Melalui Model Pembelajaran DIscovery Learning Pada Siswa Kelas X IPA SMAN 5 Bekasi Pada Tahun 2017/2018. Research and Development Journal Of Education, 5(1), 139.

Syaiful, \& Dkk. (2017). Pembelajaran Abad 21. Yogyakarta: Gava Media.

Sylvia, I., Anwar, S., \& Khairani, K. (2019). Pengembangan Instrumen Penilaian Autentik Berbasis Pendekatan Authentic Inquiry Learning Pada Mata Pelajaran Sosiologi di Sekolah Menengah Atas. Socius, 6(2), 103-120. https://doi.org/10.24036/scs.v6i2.162

Wasgito, M. A. (2014). Pengembangan Media Permainan Edukatif Teka Teki Silang ( TTS ) dalam Proses Pembelajaran Siswa Kelas VII SMP Negeri 2 Kalianget. Jurnal Pendidikan Seni Rupa, 2(1), 36-43.

Yerimadesi, Y., Putra, A., \& Ririanti, R. (2017). Efektivitas Penggunaan Modul Larutan Penyangga Berbasis Discovery Learning Terhadap Hasil Belajar Siswa Kelas XI MIA SMAN 7 Padang. Jurnal Eksakta Pendidikan, 1(1), 17-23.

Yusuf, M. (2014). Ilmu Pendidikan (D. Ilham, Ed.). Palopo: Lembaga Penerbit Kampus IAIN Palopo. 